\title{
Coordination behaviour of 1-(3,2':6',3'-terpyridin-4'-yl)ferrocene: structure and magnetic and electrochemical properties of a tetracopper dimetallomacrocycle
}

Y. Maximilian Klein, ${ }^{\mathrm{a}}$ Angelo Lanzilotto, a Alessandro Prescimone, ${ }^{\mathrm{a}}$ Karl W. Krämer, b Silvio Decurtins, b Shi-Xia Liu,b Edwin C. Constable a and Catherine E. Housecroft*a

aDepartment of Chemistry, University of Basel, Spitalstrasse 51, 4056 Basel, Switzerland

bDepartment of Chemistry and Biochemistry, University of Bern, Freiestrasse 3, 3012 Bern, Switzerland

\begin{abstract}
The discrete coordination compound $\left[\mathrm{Cu}_{4} \mathrm{Cl}_{8}(3)_{4}(\mathrm{MeOH})_{2}\right]$ is obtained from the reaction of a chloroform solution of 1-(3,2':6',3'-terpyridin-4'-yl)ferrocene (3) with a methanol solution of $\mathrm{CuCl}_{2}$; the single crystal structure of $\left[\left\{\mathrm{Cu}_{4} \mathrm{Cl}_{8}(3)_{4}(\mathrm{MeOH})_{2}\right\} \cdot 0.7 \mathrm{CHCl}_{3} \cdot 1.8 \mathrm{MeOH}\right]$ is described. Two $\left\{\mathrm{Cu}_{2} \mathrm{Cl}_{4}(\mathbf{3})_{2}(\mathrm{MeOH})\right\}$ units are connected by bridging chlorido ligands to generate a centrosymmetric tetranuclear molecule featuring face-to-face $\pi$-interactions between ferrocene units and between tpy domains. Intermolecular $\pi$-stacking of ferrocene and tpy units lead to quadruple-decker stacking motifs in the solid-state. The tetranuclear compound represents a pair of $\mu$-Cl bridged $\mathrm{Cu}(\mathrm{II})$ dimers exhibiting a weak antiferromagnetic coupling via the bridging chlorido ligands. The redox behaviour of $\mathbf{3}$ has been investigated by cyclic voltammetry and spectroelectrochemistry; a ferrocenyl oxidation process is observed for $\left[\mathrm{Cu}_{4} \mathrm{Cl}_{8}(\mathbf{3})_{4}(\mathrm{MeOH})_{2}\right]$.
\end{abstract}

Keywords: copper; divergent terypyridine; ferrocene; structure; magnetism; electrochemistry

\section{Introduction}


The spontaneous self-assembly of coordination polymers using 4,2':6',4'-- and $3,2^{\prime}: 6^{\prime}, 3^{\prime \prime}$-terpyridines (tpy) as organic linkers has seen significant growth in the last decade [1,2 ]. However, the coordination behaviour of 3,2':6',3"'-tpy ligands has received less attention than that of $4,2^{\prime}: 6^{\prime}, 4^{\prime \prime}$-tpy analogs. While the latter presents a fixed V-shaped donor set, rotation about interannular bonds in a $3,2^{\prime}: 6^{\prime}, 3^{\prime \prime}$-tpy leads to more flexible coordination modes. Typically, the central pyridine ring of both $4,2^{\prime}: 6^{\prime}, 4^{\prime \prime}-$ or $3,2^{\prime}: 6^{\prime}, 3^{\prime \prime}$-tpy ligands is non-coordinating [2]. Functionalization of the tpy unit in the 4'-position with a variety of substituents is synthetically straightforward through use of Kröhnke [3] or Wang and Hanan [4] methodologies. A ferrocenyl substituent introduces a redox-active centre as well as a structurally flexible motif. The inherent rotational freedom of the cyclopentadienyl rings about the iron centre is of particular significance in a ditopic ligand such as 1 (Scheme 1) [5]. The isomeric ferrocenyl-decorated ligands $\mathbf{2}$ and $\mathbf{3}$ differ in the directional properties associated with nitrogen donors of the outer rings. We [6] and Tian and coworkers [7] have demonstrated that combinations of $\mathbf{2}$ with zinc(II) salts lead to the assembly of metallosquares, metallohexacycles or one-dimensional coordination polymers. This structural diversity mirrors that observed with other 4,2':6',4'-tpys [1]. In the case of ligand 2 , cyclopentadienyl-tpy $\pi$-stacking interactions play a significant role in the solid state [6]. The reaction of divergent 2 with $\mathrm{CuCl}_{2}$ leads to a double stranded one-dimensional coordination polymer, the double chain being supported by $\left\{\mathrm{Cu}_{2} \mathrm{Cl}_{2}(\mu-\mathrm{Cl})_{2}\right\}$ units (Fig. 1) [6]. The divergent donor set of 2 is preorganized for this type of architecture, whereas we could envisage limiting convergent or divergent directionalities for 3 (Scheme 2) as well as intermediate vectorial definitions. We report here the assembly of a tetracopper dimetallomacrocycle and describe its structural, magnetic and electrochemical characteristics. 

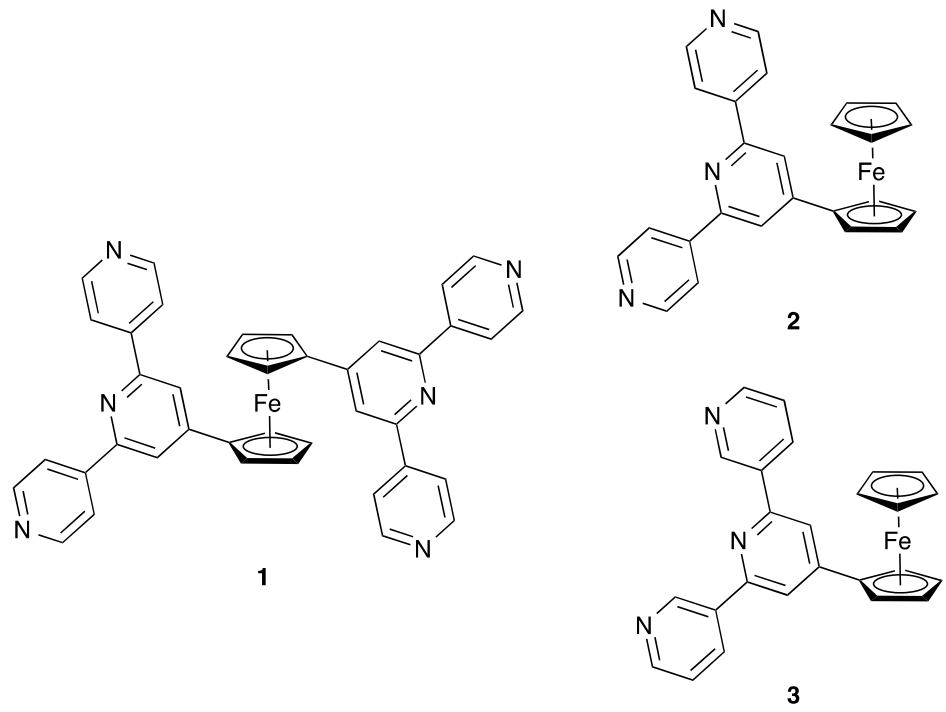

Scheme 1. Structures of ligands 1-3.

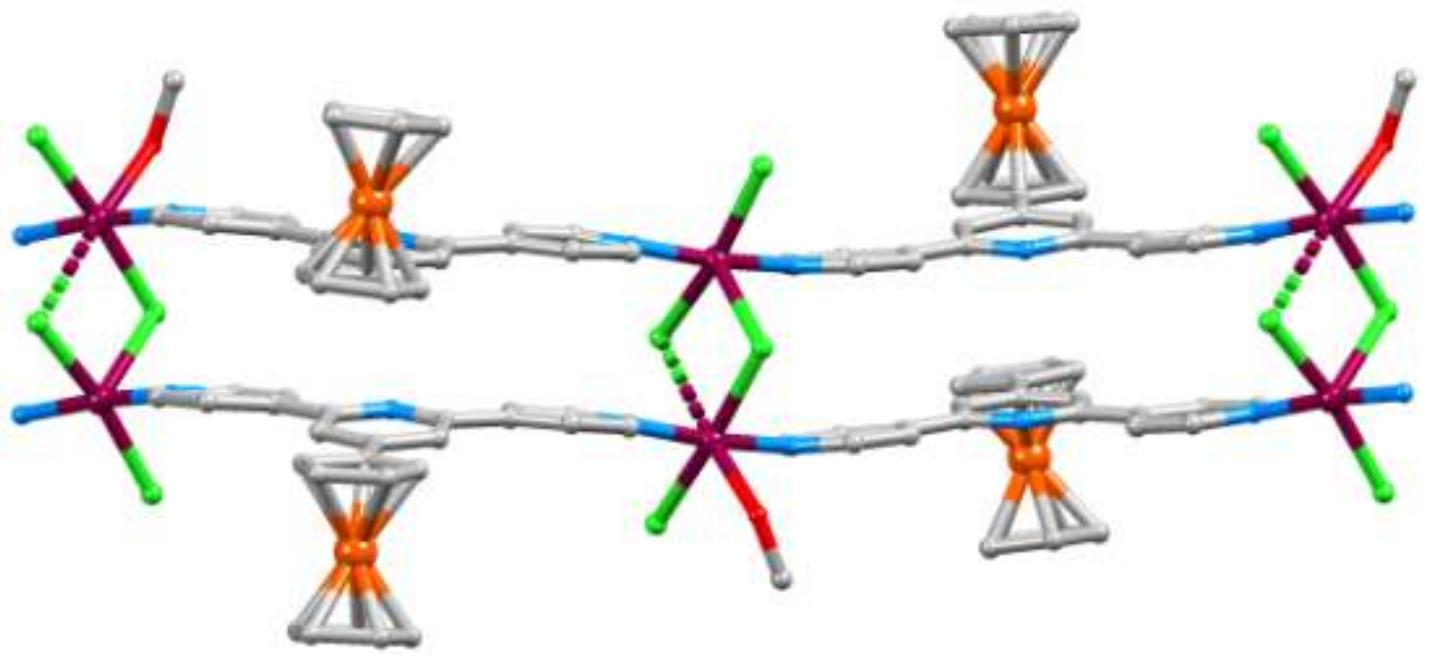

Fig. 1. Part of one double-stranded chain in the coordination polymer $\left[\left\{\mathrm{Cu}_{2} \mathrm{Cl}_{4}(2)_{2}(\mathrm{MeOH})\right\} \cdot 2.25 \mathrm{MeOH} \cdot \mathrm{H}_{2} \mathrm{O} \cdot \mathrm{CHCl}_{3}\right]_{n}[6]$.
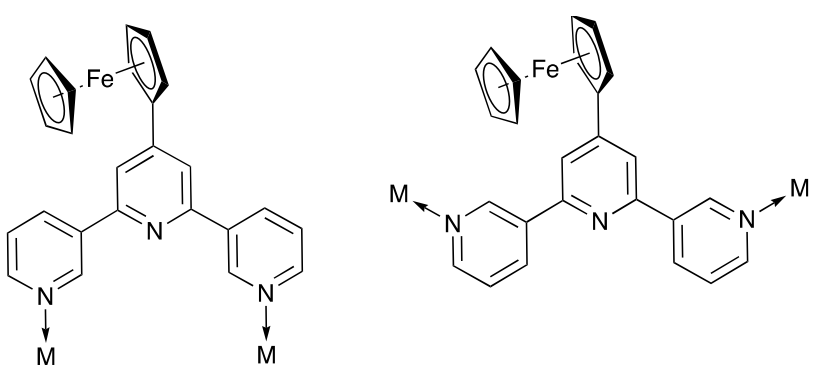

Scheme 2. Limiting convergent (left) or divergent (right) binding modes for 3. 


\section{Experimental section}

\subsection{Synthesis}

A MeOH ( $8 \mathrm{~mL})$ solution of $\mathrm{CuCl}_{2}(4.03 \mathrm{mg}, 0.03 \mathrm{mmol})$ was layered over a $\mathrm{CHCl}_{3}$ ( $5 \mathrm{~mL})$ solution of $3(12.5 \mathrm{mg}, 0.03 \mathrm{mmol})$ and the crystallization tube left to stand at room temperature. Red crystals of $\left[\left\{\mathrm{Cu}_{4} \mathrm{Cl}_{8}(3)_{4}(\mathrm{MeOH})_{2}\right\} \cdot 0.7 \mathrm{CHCl}_{3} \cdot 1.8 \mathrm{MeOH}\right](9.8 \mathrm{mg}, 0.0041 \mathrm{mmol}, 54 \%)$ were obtained after 1-2 weeks. See Fig. S1† for powder diffraction data of bulk sample.

\subsection{Crystallography}

Single crystal data were collected on a Bruker APEX-II diffractometer; data reduction, solution and refinement used APEX2, SuperFlip and CRYSTALS respectively $[8,9,10]$. Structure analysis used Mercury v. $3.6[11,12]$. In the solvent region, thermal and vibrational restraints were used. Bond distances and angles on the $\mathrm{CHCl}_{3}$ molecule were restrained to chemically reasonable values. The solvent molecules refined to non-integer occupancies that were rounded up to $0.35 \mathrm{CHCl}_{3}, 0.40 \mathrm{MeOH}$ and $0.50 \mathrm{MeOH}$.

$\left[\left\{\mathrm{Cu}_{4} \mathrm{Cl}_{8}(3)_{4}(\mathrm{MeOH})_{2}\right\} \cdot 0.7 \mathrm{CHCl}_{3} \cdot 1.8 \mathrm{MeOH}\right]: \mathrm{C}_{104.5} \mathrm{H}_{91.9} \mathrm{Cl}_{10.1} \mathrm{Cu}_{4} \mathrm{Fe}_{4} \mathrm{~N}_{12} \mathrm{O}_{3.8}, M$ = 2412.30, red block, monoclinic, space group $P 21 / c, a=14.0480(7), b=$ 22.6509(14), $c=16.6921(9) \AA, \beta=90.507(3)^{\circ}, U=5311.2(5) \AA^{3}, Z=2, D_{c}=1.508$ $\mathrm{Mg} \mathrm{m}^{-3}, \mu(\mathrm{Cu}-\mathrm{K} \alpha)=7.892 \mathrm{~mm}^{-1}, T=123 \mathrm{~K}$. Total 33091 reflections, 9788 unique, $R_{\text {int }}=0.056$. Refinement of 6392 reflections (667 parameters) with $I>2 \sigma(I)$ converged at final $R 1=0.0874(R 1$ all data $=0.1195), w R 2=0.2286(w R 2$ all data $=0.2562$ ), gof $=0.9985$.

\subsection{Magnetic Measurements}

The magnetic susceptibility measurement was made on a Quantum Design MPMS SQUID-XL magnetometer under an applied magnetic field of $10^{3}$ Oe between 300 and $1.9 \mathrm{~K}$. The magnetization measurement was conducted at $1.9 \mathrm{~K}$ up to a magnetic field of $50 \mathrm{kOe}$. The sample was prepared in a gelatin capsule. Diamagnetic correction was made for the sample using the approximation -0.45 $\times$ molecular weight $\times 10^{-6} \mathrm{~cm}^{3} \mathrm{~mol}^{-1}$, and the sample holder was corrected for by measuring directly the susceptibility of the empty capsule. 


\subsection{Electrochemistry and spectroelectrochemistry}

Electrochemical measurements were carried out with a $\mathrm{CH}$ Instruments 900B potentiostat using propylene carbonate solutions with $\left[{ }^{n} \mathrm{Bu}_{4} \mathrm{~N}\right]\left[\mathrm{PF}_{6}\right](0.1 \mathrm{M})$ as supporting electrolyte and at a scan rate of $0.1 \mathrm{~V} \mathrm{~s}^{-1}$. The working electrode was glassy carbon, the reference electrode was a leakless Ag+/AgCl (eDAQ ET069-1) electrode and the counter-electrode a platinum wire. Quoted potentials were referenced with respect to the $\mathrm{Fc}_{\mathrm{Fc}} / \mathrm{Fc}^{+}$couple. Spectroelectrochemical measurements were performed using a propylene carbonate solution of $\mathbf{3}$ or

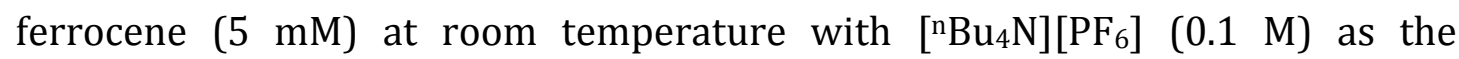
supporting electrolyte. The solution was added to an optically transparent thinlayer electrochemical (OTTLE) cell with two Pt minigrid electrodes (working and auxiliary), a silver wire as pseudoreference electrode, and a path length of $\approx 0.2$ $\mathrm{mm}$. The potential was controlled using a VersaSTAT 3 potentiostat (Princeton Applied Research). For the study of $\left[\left\{\mathrm{Cu}_{4} \mathrm{Cl}_{8}(3)_{4}(\mathrm{MeOH})_{2}\right\} \cdot 0.7 \mathrm{CHCl}_{3} \cdot 1.8 \mathrm{MeOH}\right]$, the working electrode (FTO glass, SolaronixTC022-7, $2.2 \mathrm{~mm}$ thickness, sheet resistance $\approx 7 \Omega$ square $^{-1}$ ) and counter-electrode (Solaronix Test Cell Platinum Electrode) were glued together using thermoplast hot-melt sealing foil by heating while pressing together. A suspension of finely ground $\left[\left\{\mathrm{Cu}_{4} \mathrm{Cl}_{8}(3)_{4}(\mathrm{MeOH})_{2}\right\} \cdot 0.7 \mathrm{CHCl}_{3} \cdot 1.8 \mathrm{MeOH}\right]$ in propylene carbonate containing $\left[\mathrm{nBu}_{4} \mathrm{~N}\right]\left[\mathrm{PF}_{6}\right]$ was inserted by vacuum backfilling through a hole drilled in the counter electrode. The cell was not sealed. Silver paint was applied to the edges of both electrodes to improve the electrical contact with the potentiostat terminals (two electrode setup).

\section{$3 \quad$ Results and discussion}

\subsection{Structural description}

Ligand 3 was prepared as previously reported [6]. Layering of a $\mathrm{MeOH}$ solution of copper(II) chloride over a $\mathrm{CHCl}_{3}$ solution of $\mathbf{3}$ at room temperature resulted after one or two weeks in the formation of red single crystals of $\left[\left\{\mathrm{Cu}_{4} \mathrm{Cl}_{8}(3)_{4}(\mathrm{MeOH})_{2}\right\} \cdot 0.7 \mathrm{CHCl}_{3} \cdot 1.8 \mathrm{MeOH}\right]$. The bulk sample was characterized by X-ray powder diffraction (Fig. S1). The compound crystallizes in the monoclinic space group $P 2{ }_{1} / c$, and structural analysis revealed a discrete, centrosymmetric 
tetranuclear assembly (Figs. 2 and 3). The asymmetric unit contains one [2+2] metallomacrocycle with two, near planar 3,2':6',3'--tpy units. Each outer $N$-donor of ligand 3 coordinates to one $\mathrm{Cu}(\mathrm{II})$ centre, with a trans-arrangement of $\mathrm{N}$ donors from different ligands. The [2+2] metallomacrocyclic motif is similar to those in $\left[\mathrm{Zn}_{2} \mathrm{Cl}_{2} \mathrm{~L}_{2}\right]$ and $\left[\mathrm{Zn}_{2} \mathrm{Br}_{2} \mathrm{~L}_{2}\right]$ where $\mathrm{L}$ is 4 '-(5-(N,N-diphenylamino)thien-2yl)-3,2':6',3"'-terpyridine [13]. However, in the latter, the 3,2':6',3'-tpy units are significantly twisted to accommodate both the tetrahedral geometry at zinc(II) and a centrosymmetric assembly.

Each of atoms $\mathrm{Cu} 1$ and $\mathrm{Cu} 2$ in the $\left[\mathrm{Cu}_{4} \mathrm{Cl}_{8}(3)_{4}(\mathrm{MeOH})_{2}\right]$ molecule is 5coordinate with trans- $\mathrm{N}$ atoms occupying two basal sites in the square pyramidal coordination sphere (see below). The remaining basal sites are occupied by chlorido ligands (see caption to Fig. 2 for bond lengths). The axial site of $\mathrm{Cu} 2$ is occupied by a coordinated methanol molecule $(\mathrm{Cu} 2-01=2.287(5) \AA)$. In contrast, $\mathrm{Cu} 1$ is bound to atom $\mathrm{Cl} 2 \mathrm{i}$ (symmetry code $\mathrm{i}=1-\mathrm{x}, 1-\mathrm{y},-\mathrm{z}$ ) and the latter forms a bridge between the first [2+2] metallomacrocycle and its symmetry related partner $(\mathrm{Cu} 1-\mathrm{Cl} 2 \mathrm{i}=2.5459(19) \AA)$. The square-pyramidal coordination description is consistent with values of $\tau$ (defined by Addison et al. [14]) of 0.051 for atom $\mathrm{Cu} 2$ and 0.263 for $\mathrm{Cu} 1$. We note, however, that the terminal chlorido ligand $\mathrm{Cl} 4 \mathrm{i}$ faces $\mathrm{Cu} 2$ (Fig. 2) leading to a weak interaction $(\mathrm{Cu} 2 \ldots \mathrm{Cl} 4 \mathrm{i}=3.158(2) \AA ̊$.$) . In the one-dimensional polymer$ $\left[\left\{\mathrm{Cu}_{2} \mathrm{Cl}_{4}(2)_{2}(\mathrm{MeOH})\right\} \cdot 2.25 \mathrm{MeOH} \cdot \mathrm{H}_{2} \mathrm{O} \cdot \mathrm{CHCl}_{3}\right]_{n}[6]$, one $\mathrm{Cu}-\mathrm{Cl}$ contact in the $\left\{\mathrm{Cu}_{2}(\mu-\right.$ $\mathrm{Cl}_{2}$ \} bridging unit is also longer than the other three $(2.3688(14), 2.6392(13)$, 2.3008(14) and 3.0436(14) ^) (Fig. 1). The similarity of the bridging units in $\left[\left\{\mathrm{Cu}_{4} \mathrm{Cl}_{8}(3)_{4}(\mathrm{MeOH})_{2}\right\} \cdot 0.7 \mathrm{CHCl}_{3} \cdot 1.8 \mathrm{MeOH}\right]$ and $\left[\left\{\mathrm{Cu}_{2} \mathrm{Cl}_{4}(2)_{2}(\mathrm{MeOH})\right\} \cdot 2.25 \mathrm{MeOH} \cdot \mathrm{H}_{2} \mathrm{O} \cdot \mathrm{CHCl}_{3}\right]_{n}$ is reflected in the comparable $\mathrm{Cu}$...Cu separations of 3.668(1) versus 3.667(1) Å. 


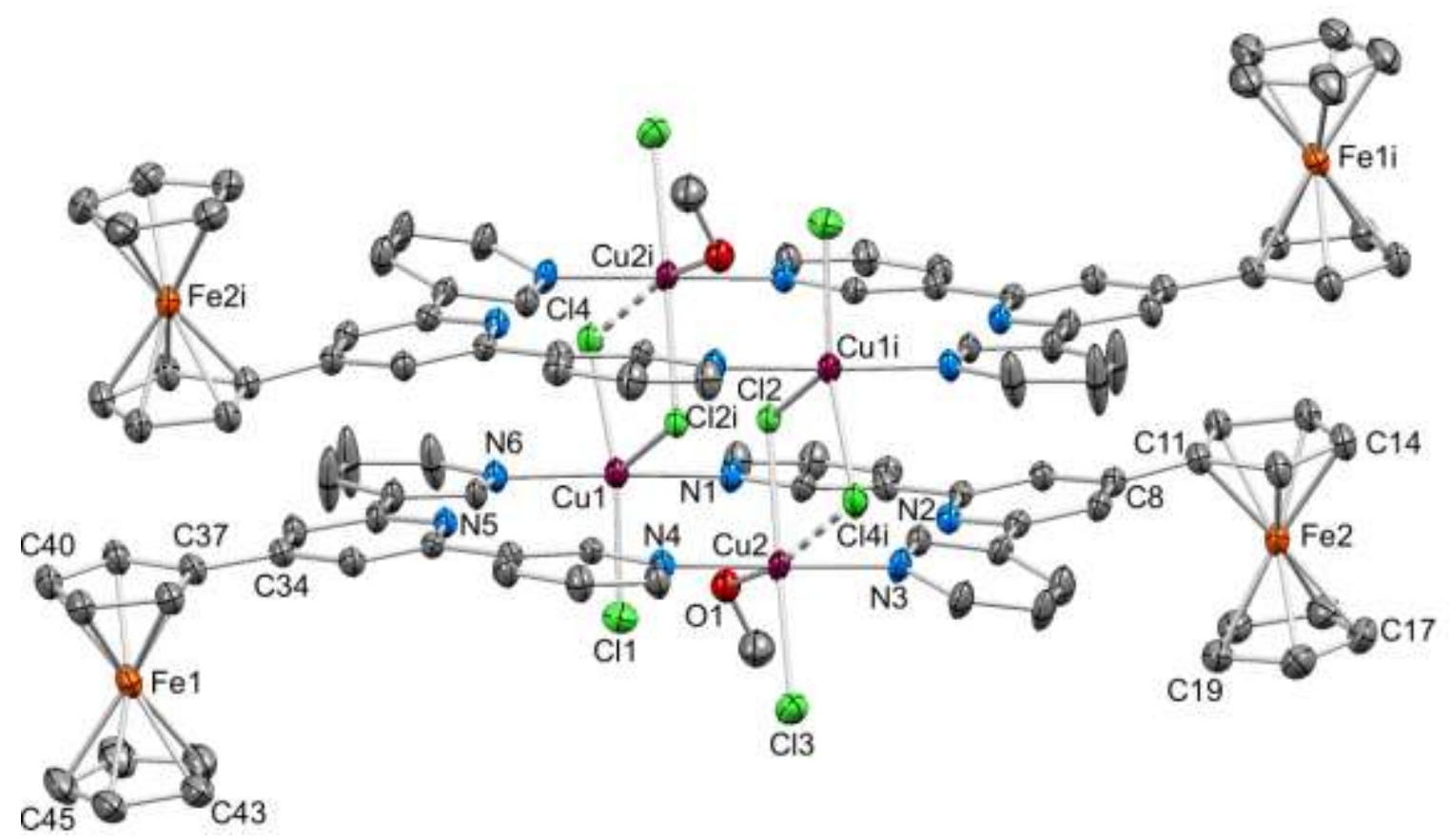

Fig. 2. Structure of the $\left[\mathrm{Cu}_{4} \mathrm{Cl}_{8}(3)_{4}(\mathrm{MeOH})_{2}\right]$ molecule in $\left[\left\{\mathrm{Cu}_{4} \mathrm{Cl}_{8}(3)_{4}(\mathrm{MeOH})_{2}\right\} \cdot 0.7 \mathrm{CHCl}_{3} \cdot 1.8 \mathrm{MeOH}\right]$. Hydrogen atoms are omitted and ellipsoids are plotted at $30 \%$ probability level. Selected bond distances and angles: $\mathrm{Cu} 1-\mathrm{Cl} 1=2.269(2), \mathrm{Cu} 1-\mathrm{Cl} 4=2.3201(19), \mathrm{Cu} 1-\mathrm{Cl} 2^{\mathrm{i}}=2.5459(19), \mathrm{Cu} 2-$ $\mathrm{Cl} 2=2.3471(17), \mathrm{Cu} 2-\mathrm{Cl} 3=2.309(2), \mathrm{Cu} 1-\mathrm{N} 1=2.018(6), \mathrm{Cu} 1-\mathrm{N} 6=2.007(5)$, $\mathrm{Cu} 2-\mathrm{N} 3=2.016(5), \mathrm{Cu} 2-\mathrm{N} 4=2.024(5), \mathrm{Cu} 2-01=2.287(5) \AA ̊ 2 \mathrm{~N} 1-\mathrm{Cu} 1-\mathrm{N} 6=$ 173.1(3), N3-Cu2-N4 = 174.2(3), Cl2-Cu2-Cl3 = 177.24(8), Cl4 $-\mathrm{Cu} 1-\mathrm{Cl} 1=$ 157.32(9) $\mathrm{Cu} 1^{\mathrm{i}}-\mathrm{Cl} 2-\mathrm{Cu} 2=97.03(6)^{\circ}$.

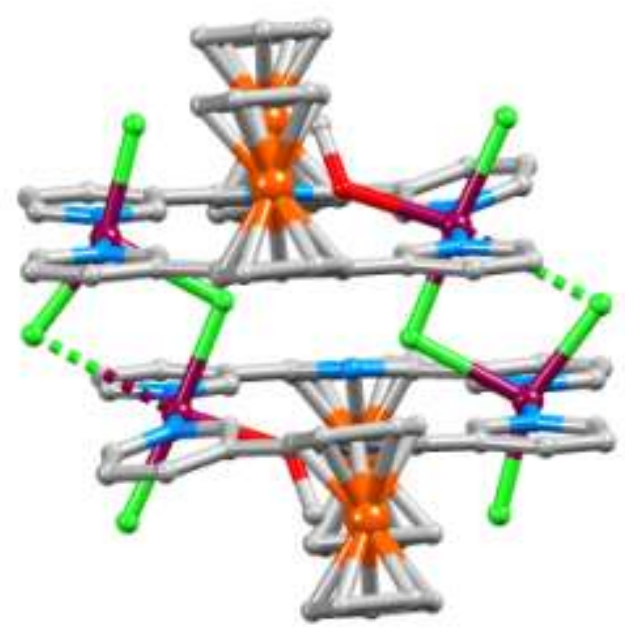

Fig. 3. View of the $\left[\mathrm{Cu}_{4} \mathrm{Cl}_{8}(3)_{4}(\mathrm{MeOH})_{2}\right]$ molecule in $\left[\left\{\mathrm{Cu}_{4} \mathrm{Cl}_{8}(3)_{4}(\mathrm{MeOH})_{2}\right\} \cdot 0.7 \mathrm{CHCl}_{3} \cdot 1.8 \mathrm{MeOH}\right]$ showing the interconnection of [2+2] metallomacrocycles. Hydrogen atoms omitted. 
The angles between the planes of the pyridine rings containing $\mathrm{N} 1 / \mathrm{N} 2$, $\mathrm{N} 2 / \mathrm{N} 3, \mathrm{~N} 4 / \mathrm{N} 5$ and N5/N6 are 11.9, 21.4, 8.9 and 8.5 ${ }^{\circ}$, respectively. Both independent ferrocenyl units exhibit very little twist with respect to the central pyridine ring of ligand $\mathbf{3}$ angle to which each is bonded (angles between the pyridine and attached cyclopentadienyl rings $=7.7$ and $5.3^{\circ}$ ). The latter is associated with efficient face-to-face $\pi$-interactions between ferrocenyl units of symmetry-related metallomacrocycles (space-filling representation in Fig. 4). The angle between pairs of stacked cyclopentadienyl rings is $1.9^{\circ}$, and the intercentroid distance is $3.52 \AA$. The stacking interactions extend to pairs of $3,2^{\prime}: 6^{\prime}, 3^{\prime \prime}-$ tpy units (Fig. 4) which exhibit an optimal slipped orientation. For the three independent pairs of stacked pyridine rings, centroid...ring plane distances are 3.69, 3.36 and $3.47 \AA$, and centroid...centroid separations are 3.90, 3.67 and 3.71 $\AA$ A.

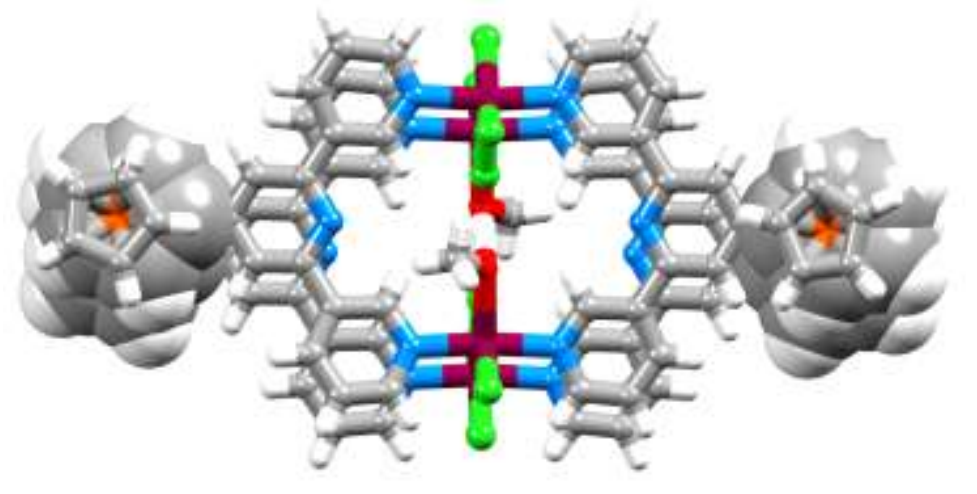

Fig. 4. Face-to-face $\pi$-stacking of ferrocenyl units (space-filling representation) and between 3,2':6',3"-tpy units.

The $\left[\mathrm{Cu}_{4} \mathrm{Cl}_{8}(\mathbf{3})_{4}(\mathrm{MeOH})_{2}\right]$ molecules pack into sheets lying in the $b c$-plane (Fig. S2). The space between the layers is filled by $\mathrm{CHCl}_{3}$ and $\mathrm{MeOH}$ solvent molecules in partially occupied positions. Within a sheet, centrosymmetric pairs of $\left[\mathrm{Cu}_{4} \mathrm{Cl}_{8}(\mathbf{3})_{4}(\mathrm{MeOH})_{2}\right]$ molecules engage in face-to-face $\pi$-interactions between ferrocene and tpy domains. This extends the intramolecular $\pi$-interactions between ferrocenyl units into a quadruple-decker stack. This is shown in Fig. 5 for three adjacent pairs of molecules; for the red molecules, both intra- and intermolecular $\pi$-stacking is shown in spacefilling representation. Tightly associated pairs of molecules interlock with one another into the twodimensional sheet assembly. 


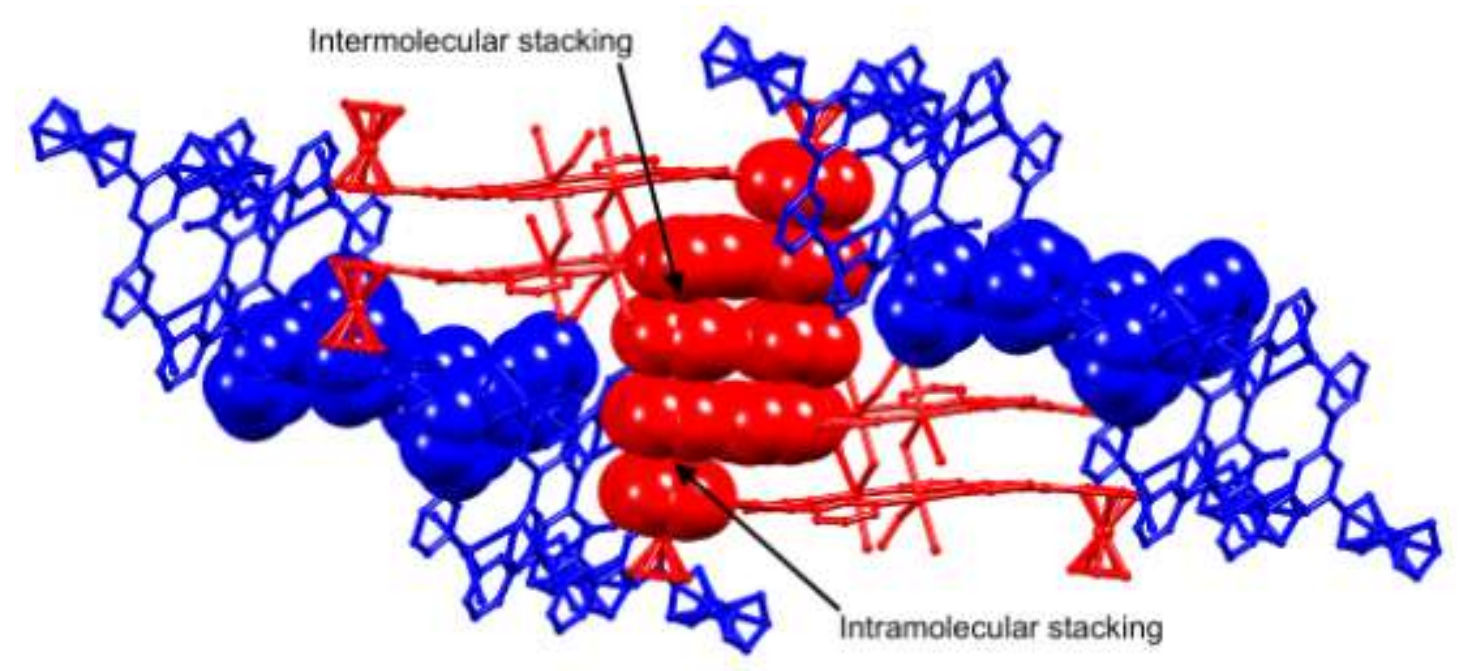

Fig. 5. Adjacent centrosymmetric pairs of $\left[\mathrm{Cu}_{4} \mathrm{Cl}_{8}(3)_{4}(\mathrm{MeOH})_{2}\right]$ molecules (red or blue). $\pi$-Stacking interactions are shown in spacefilling representation, both intra- and intermolecular for the red molecules, and only intermolecular for the blue molecules.

\subsection{Magnetic Measurements}

Among studies focusing on magnetism, the structural motif of chlorido-bridged copper(II) compounds is well represented in doubly-bridged dimers $[15,16]$ and in infinite chains $[17,18,19,20,21]$, but there are fewer examples of discrete copper(II) compounds featuring singly-bridged $\mathrm{Cu}-\mathrm{Cl}-\mathrm{Cu}$ units $\left[22,23,{ }^{24}\right]$. $\left[\left\{\mathrm{Cu}_{4} \mathrm{Cl}_{8}(3)_{4}(\mathrm{MeOH})_{2}\right\} \cdot 0.7 \mathrm{CHCl}_{3} \cdot 1.8 \mathrm{MeOH}\right]$ was investigated by magnetic susceptibility measurements. The $\chi_{\mathrm{m}} T(T)$ plot (Fig. 6) of a polycrystalline sample of $\left[\left\{\mathrm{Cu}_{4} \mathrm{Cl}_{8}(3)_{4}(\mathrm{MeOH})_{2}\right\} \cdot 0.7 \mathrm{CHCl}_{3} \cdot 1.8 \mathrm{MeOH}\right]$ exhibits a value of $1.04 \mathrm{~cm}^{3} \mathrm{~K} \mathrm{~mol}^{-1}$ at $300 \mathrm{~K}$ (per two $\mathrm{Cu}(\mathrm{II})$ ions) which decreases only slightly with lowering the temperature to around $50 \mathrm{~K}$. At lower temperatures, a pronounced decrease of $\chi_{\mathrm{m}} T$ is evident leading to a value of $0.39 \mathrm{~cm}^{3} \mathrm{~K} \mathrm{~mol}^{-1}$ at $1.9 \mathrm{~K}$. The shape of the curve is typical for antiferromagnetic exchange interactions, though with weak coupling between adjacent $\mathrm{Cu}(\mathrm{II})$ centers, and the high temperature $\chi_{\mathrm{m}} T$ values point to a $g$ factor $>2$ and two magnetically isolated spin doublets (half of the molecule $\left.\left[\mathrm{Cu}_{4} \mathrm{Cl}_{8}(3)_{4}(\mathrm{MeOH})_{2}\right]\right)$. In a first approach, the data over the whole temperature range were modeled following the theoretical approach for a dimeric $\mathrm{Cu}(\mathrm{II})$ system (twice $\mathrm{S}=1 / 2$ ) assuming isotropic intradimer interactions. In other words, the molecule $\left[\mathrm{Cu}_{4} \mathrm{Cl}_{8}(3)_{4}(\mathrm{MeOH})_{2}\right]$ is viewed as a magnetically uncoupled pair of $\mu$-Cl bridged $\mathrm{Cu}(\mathrm{II})$ dimers where the magnetic superexchange 
is likely propagated via the bridging chlorido ligands. A least-squares fit resulted in the parameters $g=2.4$ and $J=16.2(4) \mathrm{K}\left(11.2(3) \mathrm{cm}^{-1}\right)$ based on the Hamiltonian $\mathbf{H}=J\left(\mathbf{S}_{1} \cdot \mathbf{S}_{2}\right)$. As it is obvious from the fitted curve in Fig. 6, this model does not capture very well the curvature of the experimental $\chi_{\mathrm{m}} T$ values below $50 \mathrm{~K}$, and the least-squares fit clearly compensates for it in the high temperature region. Next, a model with two J parameters was applied [25], one for the mono $\mu$-Cl bridges and the other one for additional weak coupling pathways through two tpy units connecting the two adjacent $\mathrm{Cu}(\mathrm{II})$ ions of each [Cu-Cl(bridge)-Cu] dimer. However, also this model did not improve the fit over the whole temperature range. Therefore, the first model with only one $J$ parameter was taken for a fit over the lower temperature regime only, while taking into account that the information about the coupling strength lies predominantly in that temperature range. The inset of Figure 6 shows now a reasonable fit for the 50-1.9 $\mathrm{K}$ range resulting in the parameters $g=2.3$ and $J=$ $13.0(2) \mathrm{K}\left(9.0(1) \mathrm{cm}^{-1}\right)$. This $J$ value lies within the range of literature values [19] of $\mu$-Cl bridged $\mathrm{Cu}(\mathrm{II})$ compounds. Fig. S3 shows the magnetization data for the compound taken at $1.9 \mathrm{~K}$.

For mono-chlorido bridged $\mathrm{Cu}(\mathrm{II})$ complexes, no magneto-structural correlations have been reported so far. In this context it must be recognized that the symmetry of the coordination environment for the $\mathrm{Cu}$ (II) ions is very low and consequently, an extensive mixing of the d-orbitals occurs. Thus, besides bonddistances, the angle of the $\mathrm{Cu}-\mathrm{Cl}$ (bridging)- $\mathrm{Cu}$ unit and the symmetry of the coordination environment, the degree of spin density of the unpaired electron of the $\mathrm{Cu}(\mathrm{II})$ ions on the bridge is decisive for the coupling strength. 


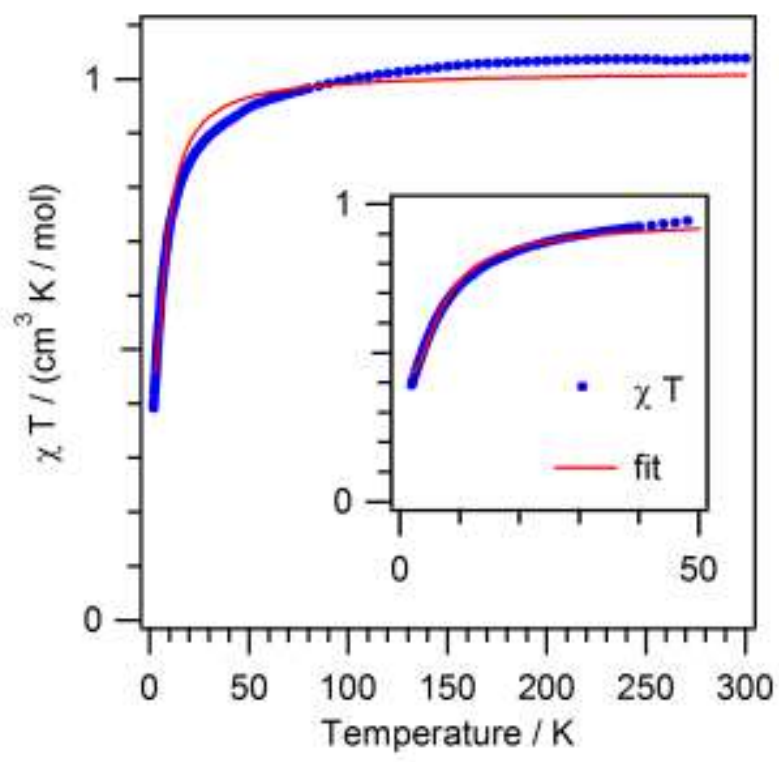

Fig. 6. Thermal variation of $\chi_{\mathrm{m}} T$ for $\mathbf{1}$ (per two $\mathrm{Cu}(\mathrm{II})$ ions); inset highlights the 50 to $1.9 \mathrm{~K}$ region. Solid lines represent fitted curves.

\subsection{Electrochemistry and spectroelectrochemistry}

An investigation of the redox activity of $\left[\mathrm{Cu}_{4} \mathrm{Cl}_{8}(3)_{4}(\mathrm{MeOH})_{2}\right]$ was hindered by the very low solubility of solid $\left[\left\{\mathrm{Cu}_{4} \mathrm{Cl}_{8}(3)_{4}(\mathrm{MeOH})_{2}\right\} \cdot 0.7 \mathrm{CHCl}_{3} \cdot 1.8 \mathrm{MeOH}\right]$ in common solvents. Propylene carbonate was the most suitable solvent of a range investigated. Cyclic voltammograms (two cycles) of an orange solution of $\mathbf{3}$ are shown in Fig. 7. The ferrocenyl unit undergoes a reversible oxidation at $+0.12 \mathrm{~V}$ $\left(E_{\mathrm{pc}}-E_{\mathrm{pa}}=40 \mathrm{mV}\right)$ referenced to external $\mathrm{Fc} / \mathrm{Fc}^{+}$. The shift in oxidation potential on going from ferrocene to 3 was confirmed using an internal $\mathrm{Fc} / \mathrm{Fc}^{+}$reference (Fig. S4). Within the solvent accessible window a quasi-reversible reduction process $\left(-2.44 \mathrm{~V}, E_{\mathrm{pc}}-E_{\mathrm{pa}} \sim 100 \mathrm{mV}\right)$ presumably centred on the tpy unit is also observed (Fig. 7). Addition of crystals of $\left[\left\{\mathrm{Cu}_{4} \mathrm{Cl}_{8}(3)_{4}(\mathrm{MeOH})_{2}\right\} \cdot 0.7 \mathrm{CHCl}_{3} \cdot 1.8 \mathrm{MeOH}\right]$ to propylene carbonate resulted in a pale orange solution in contact with crystalline material. The $\mathrm{CV}$ of the pale orange solution is compared with that of ligand 3 in Fig. 7 and the close similarity of the two cycles suggests that they both arise from the same redox active motif or the same compound. We cannot state whether the redox activity is from the intact species $\left[\left\{\mathrm{Cu}_{4} \mathrm{Cl}_{8}(3)_{4}(\mathrm{MeOH})_{2}\right]\right.$ or from free $\mathbf{3}$ arising from complex dissociation. 


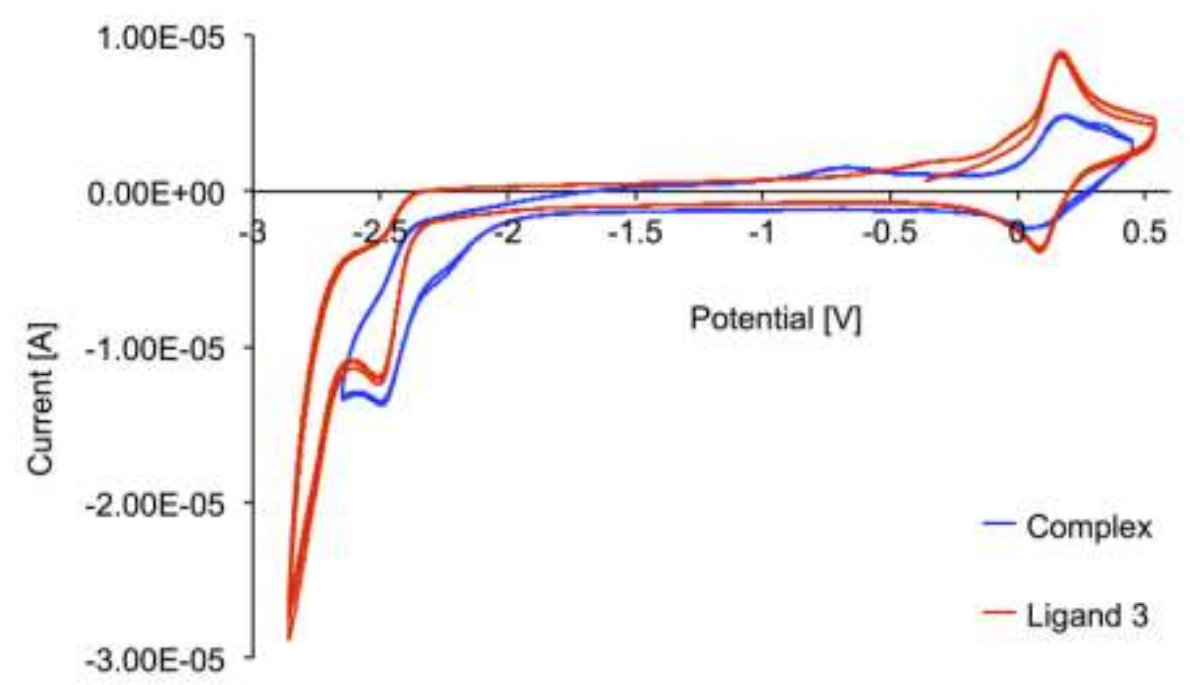

Fig. 7. Cyclic voltammograms (two scans) of propylene carbonate solutions of $\mathbf{3}$ (red) and $\left[\mathrm{Cu}_{4} \mathrm{Cl}_{8}(3)_{4}(\mathrm{MeOH})_{2}\right]$ (blue) with $\left[{ }^{\mathrm{n}} \mathrm{Bu}_{4} \mathrm{~N}\right]\left[\mathrm{PF}_{6}\right]$ supporting electrolyte, and scan rate of $0.1 \mathrm{~V} \mathrm{~s}^{-1}$. Referenced with respect to external $\mathrm{Fc} / \mathrm{Fc}^{+}$. See also Fig. S4.

To further investigate the compound, we prepared a suspension of finely ground crystals of $\left[\left\{\mathrm{Cu}_{4} \mathrm{Cl}_{8}(3)_{4}(\mathrm{MeOH})_{2}\right\} \cdot 0.7 \mathrm{CHCl}_{3} \cdot 1.8 \mathrm{MeOH}\right]$ in propylene carbonate containing $\left[\mathrm{nBu}_{4} \mathrm{~N}\right]\left[\mathrm{PF}_{6}\right]$ to study the pseudo-solid-state electrochemical behaviour. This paste was inserted into the cavity between two FTO glass electrodes, one of which was coated with platinum (see experimental section), a fabrication that mimics a dye-sensitized solar cell [26]. Figure 8 shows a CV with five consecutive cycles obtained from this configuration. The compound undergoes a reversible, iron-centred oxidative process at $+0.01 \mathrm{~V}$ and in this case we assign the process as arising from $\left[\mathrm{Cu}_{4} \mathrm{Cl}_{8}(3)_{4}(\mathrm{MeOH})_{2}\right]$. The reductive process seen in Fig. 8 around $-0.9 \mathrm{~V}$ is reproducible in each cycle.

Spectroelectrochemical data for compound $\mathbf{3}$ were also recorded. The oxidative cycle for a propylene carbonate solution of $\mathbf{3}$ was investigated by recording an absorbance spectrum every $0.1 \mathrm{~V}$, from 0 to $+1.5 \mathrm{~V}$ and back from +1.5 to $0 \mathrm{~V}$ (Fig. 9). The absorption maximum at $461 \mathrm{~nm}$ responsible for the orange colour of 3 diminishes and is replaced by a broad band with $\lambda_{\max } \sim 660$ $\mathrm{nm}$, consistent with the typical blue colour of ferrocenium $\left(\mathrm{Fc}^{+}\right)$species. The absorption spectra corresponding to $\mathbf{3}$ and [3]+ are presented in Fig. S5. 


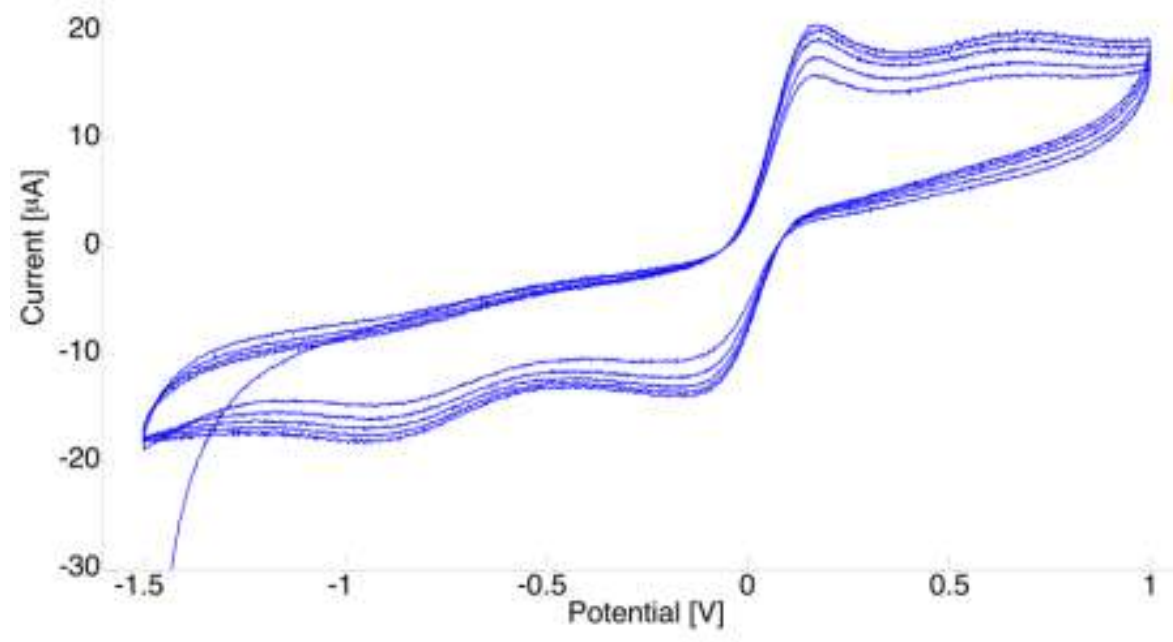

Fig. 8. Cyclic voltammogram (five cycles) of a cell (see text) containing a paste of $\left[\left\{\mathrm{Cu}_{4} \mathrm{Cl}_{8}(3)_{4}(\mathrm{MeOH})_{2}\right\} \cdot 0.7 \mathrm{CHCl}_{3} \cdot 1.8 \mathrm{MeOH}\right] /$ propylene carbonate $/\left[{ }^{\mathrm{n}} \mathrm{Bu}_{4} \mathrm{~N}\right]\left[\mathrm{PF}_{6}\right]$ paste. Scan rate $0.1 \mathrm{~V} \mathrm{~s}^{-1}$.

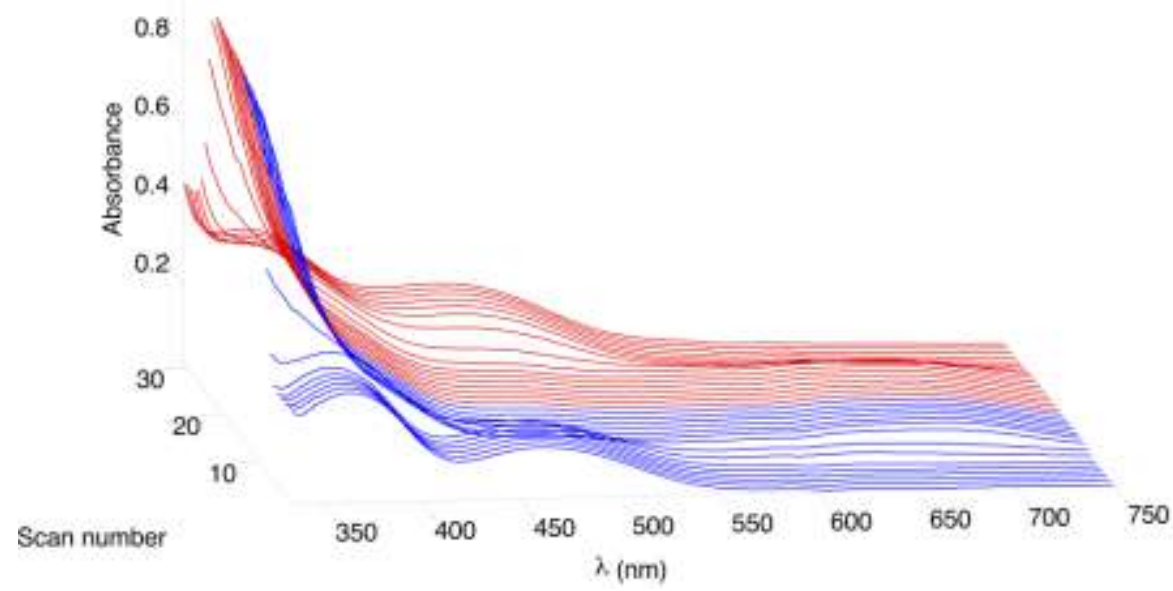

Fig. 9. Spectroelectrochemical data for the oxidative cycle of $\mathbf{3}$ (propylene carbonate solution, $\left[{ }^{\left.\mathrm{B}_{4} \mathrm{~N}\right]}\left[\mathrm{PF}_{6}\right]\right.$ as supporting electrolyte) starting from $0 \mathrm{~V}$ (first blue line, scan 1) to $+1.5 \mathrm{~V}$ (last blue line, scan 16) and back from $+1.5 \mathrm{~V}$ (first red line, scan 17) to $0 \mathrm{~V}$ (last red line, scan 31 ).

\section{Conclusion}

We have described the formation of the discrete complex $\left[\mathrm{Cu}_{4} \mathrm{Cl}_{8}(3)_{4}(\mathrm{MeOH})_{2}\right]$ and the single crystal structure of $\left.\left[\mathrm{Cu}_{4} \mathrm{Cl}_{8}(3)_{4}(\mathrm{MeOH})_{2}\right\} \cdot 0.7 \mathrm{CHCl}_{3} \cdot 1.8 \mathrm{MeOH}\right]$. Two $\left\{\mathrm{Cu}_{2} \mathrm{Cl}_{4}(3)_{2}(\mathrm{MeOH})\right\}$ metallomacrocycles are linked through bridging chlorido ligands to generate a centrosymmetric tetracopper dimetallomacrocycle. The two metallomacrocycles engage in efficient face-to-face $\pi$-interactions between ferrocene units and between tpy domains. Intermolecular packing interactions 
extend the former into quadruple-decker stacking motifs. From the perspective of magnetic exchange interactions, the tetranuclear compound can be viewed as a pair of $\mu$-Cl bridged $\mathrm{Cu}$ (II) dimers exhibiting a weak antiferromagnetic coupling via the bridging chloride ligands. Compound $\mathbf{3}$ undergoes a ferrocenyl-centred reversible oxidation at $+0.12 \mathrm{~V}$ and a tpy-based quasi-reversible reduction process at $-2.44 \mathrm{~V}$. Spectroelectrochemistry showed that the oxidation process is accompanied by loss of an absorption at $461 \mathrm{~nm}$ and the appearance of an absorption at $660 \mathrm{~nm}$; this process is fully reversible. Electrochemical data for $\left[\mathrm{Cu}_{4} \mathrm{Cl}_{8}(3)_{4}(\mathrm{MeOH})_{2}\right]$ was obtained using a suspension of the material in propylene carbonate; the only well-defined process was a ferrocene-based oxidation.

\section{Acknowledgements}

We thank the Swiss National Science Foundation (Grant numbers 200020_162631 and 200020-150257, and as part of the NCCR Molecular Systems Engineering) and the University of Basel for support.

\section{Appendix A. Supplementary data}

CCDC 1530973 contains the supplementary crystallographic data for $\left[\left\{\mathrm{Cu}_{4} \mathrm{Cl}_{8}(3)_{4}(\mathrm{MeOH})_{2}\right\} \cdot 0.7 \mathrm{CHCl}_{3} \cdot 1.8 \mathrm{MeOH}\right]$. These data can be obtained free of charge via http://www.ccdc.cam.ac.uk/conts/retrieving.html, or from the Cambridge Crystallographic Data Centre, 12 Union Road, Cambridge CB2 1EZ, UK; fax: (+44) 1223-336-033; or e-mail: deposit@ccdc.cam.ac.uk.

\section{References}

[1] C.E. Housecroft, Dalton Trans. 43 (2014) 6594.

[2] C.E. Housecroft, CrystEngComm 17 (2015) 7461.

[3] F. Kröhnke, Synthesis (1976) 1.

[4] J. Wang and G.S. Hanan, Synlett (2005) 1251. 
[5] Y.M. Klein, A. Prescimone, E.C. Constable, C.E. Housecroft, Inorg. Chem. Comm. 70 (2016) 118.

[6] Y. M. Klein, A. Prescimone, E. C. Constable, and C. E. Housecroft, Aus. J. Chem. (2017) advance article, doi.org/10.1071/CH16527.

[7] L. Xiao, L. Zhu, Q. Zeng, Q. Liu, J. Zhang, S. Li, H. Zhou, S. Zhang, J. Wu, Y. Tian, J. Organomet. Chem. 22 (2015) 789.

[8] Bruker Analytical X-ray Systems, Inc., 2006, APEX2, version 2 User Manual, M86-E01078, Madison, WI.

[9] L. Palatinus, G. Chapuis, J. Appl. Cryst. 40 (2007) 786.

[10] P. W. Betteridge, J. R. Carruthers, R. I. Cooper, K. Prout, D. J. Watkin, J. Appl. Cryst. 36 (2003) 1487.

[11] I. J. Bruno, J. C. Cole, P. R. Edgington, M. K. Kessler, C. F. Macrae, P. McCabe, J. Pearson, R. Taylor, Acta Cryst. B 58 (2002) 389.

[12] C. F. Macrae, I. J. Bruno, J. A. Chisholm, P. R. Edgington, P. McCabe, E. Pidcock, L. Rodriguez-Monge, R. Taylor, J. van de Streek, P. A. Wood, J. Appl. Cryst. 41 (2008) 466.

[13] M. Zhao, J. Tan, J. Su, J. Zhang, S. Zhang, J. Wu, Y. Tian, Dyes Pigments 130 (2016) 216.

[14] A. W. Addison, T. N. Rao, J. Reedijk, J. van Rijn, G. C. Verschoor, J. Chem. Soc., Dalton Trans. (1984) 1349.

[15] W. E. Marsh, K. C. Patel, W. E. Hatfield, D. J. Hodgson, Inorg. Chem. 22 (1983) 511.

[16] W. A. Alves, R. H. de Almeida Santos, A. Paduan-Filho, C. C. Becerra, A. C. Borin, A.M. Da Costa Ferreira, Inorg. Chim. Acta 357 (2004) 2269.

[17] W. E. Estes, W. E. Hatfield, J. A. C. van Ooijen, J. Reedijk, J. Chem. Soc., Dalton Trans. 1980, 2121.

[18] S. Decurtins, H. W. Schmalle, P. Schneuwly, L.-M. Zheng, J. Ensling, A. Hauser, Inorg. Chem. 1995, 34, 5501.

[19] H. Grove, J. Sletten, M. Julve, F. Lloret, J. Chem. Soc., Dalton Trans. (2001) 2487 and references cited therein. 
[20] F. J. Barros-Garcia, A. Bernalte-Garcia, F. J. Higes-Rolando, F. Luna-Giles, A. M. Pizarro-Galan, E. Vinuelas-Zahinos, Z. Anorg. Allg. Chem. 631 (2005) 1898.

[21] S. Walha, H. Naili, S. Yahyaoui, B. F. Ali, M. M. Turnbull, T. Mhiri, J. Supercond. Nov. Magn. 26 (2013) 437.

[22] M. Du, Y. M. Guo, X. H. Bu, J. Ribas, M. Monfort, New. J. Chem. 26 (2002) 939.

[23] G. Seeber, B. M. Kariuki, L. Cronin, P. Kögerler, Polyhedron 24 (2005) 1651.

[24] C. Deckert, D. Bittner, L.M. Carrella, D. Schollmeyer, E. Rentschler, Eur. J. Inorg. Chem. (2016) 1738.

[25] J. W. Hall, W. E. Estes, E. D. Estes, R. P. Scaringe, W. E. Hatfield, Inorg. Chem. 16 (1977) 1572.

[26] See for example: Y. M. Klein, M. Willgert, A. Prescimone, E. C. Constable, C. E. Housecroft, Dalton Trans. 45 (2016) 465. 


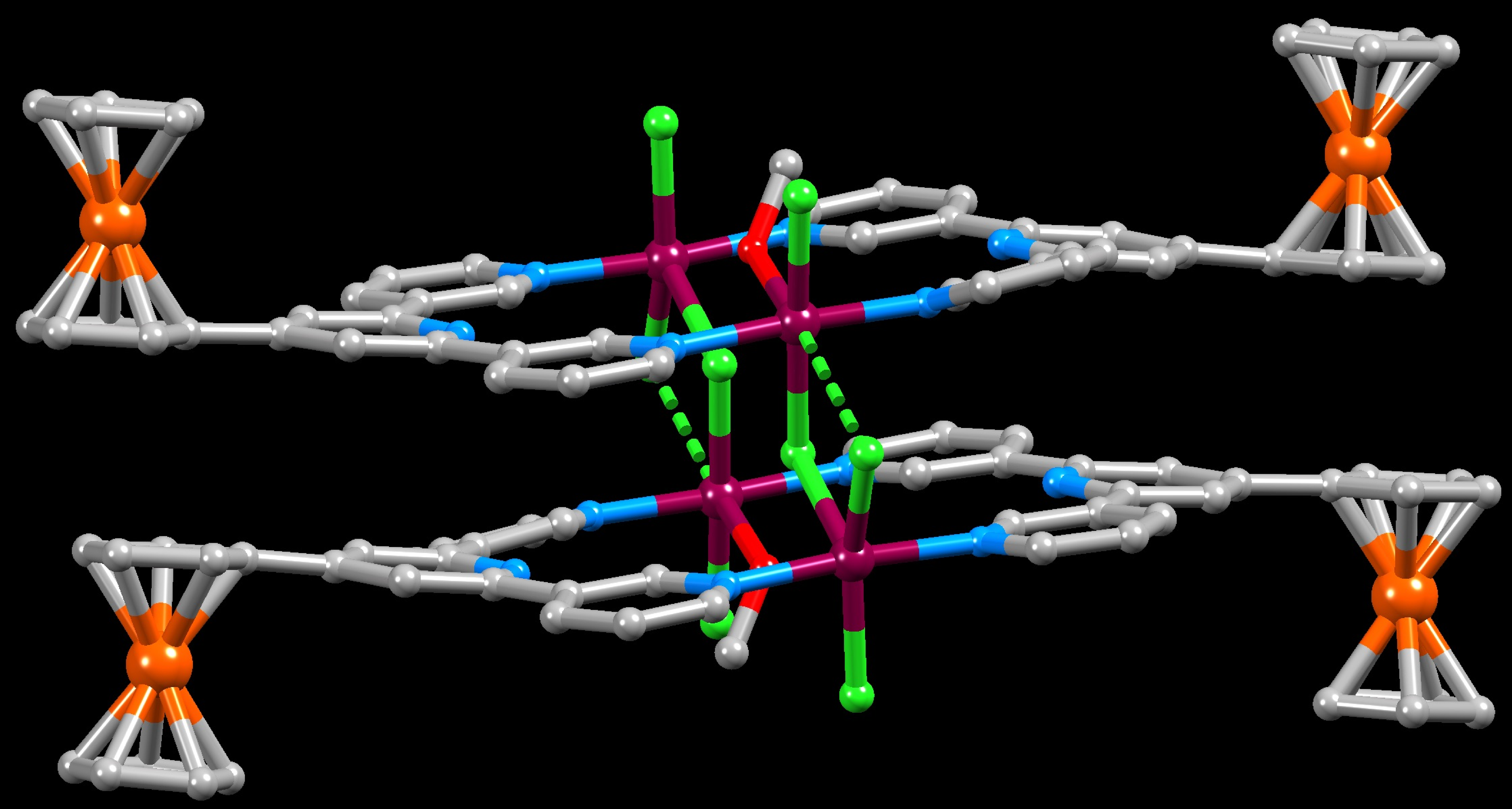

